\title{
SMALL-SIZED ENTERPRISES MANAGEMENT IN THE ASPECT OF ORGANIZATIONAL CULTURE
}

\author{
GESTÃO DE PEQUENAS EMPRESAS NO ASPECTO DA CULTURA \\ ORGANIZACIONAL
}

\section{LA GESTIÓN DE LAS PEQUEÑAS EMPRESAS EN EL ASPECTO DE LA CULTURA ORGANIZACIONAL}

Dorota Klimecka-Tatar

Department of Production Engineering and Safety, associate professor. Czestochowa University of Technology, Polonia

d.klimecka-tatar@pcz.pl

https://orcid.org/0000-0001-6212-6061

Marta Niciejewska

Department of Production Engineering and Safety, assistant professor. Czestochowa University of Technology, Polonia

marta.niciejewska@pcz.pl

https://orcid.org/0000-0002-9530-3455

Editor Científico: José Edson Lara

Organização Comitê Científico

Double Blind Review pelo SEER/OJS

Recebido em 01.10.2020

Aprovado em 26.02.2021

Este trabalho foi licenciado com uma Licença Creative Commons - Atribuição - Não Comercial 3.0 Brasil 


\begin{abstract}
This paper presents the results of research based the questionnaire by Cammeron and Quinn. The research was carried out among employees of small-sized enterprises with various business profiles. The elements that make up the profile of the organizational culture in the company (management style, strategic plans, atmosphere, remuneration system, bonding mechanisms, leadership and basic assumptions in the company) were evaluated. The analysis lead to the comparision between expected state with the current state. The result of the current state is characterized by the dominant profile of organizational culture in the company, while the result of the expected state provides information on the preferences and expectations of employees in relation to the dominant profile of organizational culture desired in the company. It was faund that the present state in the small-sized manufacturing, service, trade and mixed enterprises is characterized with profile of market culture with elements of hierarchy organizational culture, while the expected state is characterized with profile of clan culture with elements of adhocracy, market and hierarchy organizational culture.
\end{abstract}

Keywords: organizational culture, small-sized enterprises, SME, safety management,

\title{
Resumo
}

Este artigo apresenta os resultados de uma pesquisa baseada no questionário de Cammeron e Quinn. A pesquisa foi realizada entre funcionários de pequenas empresas com diversos perfis de negócios. Foram avaliados os elementos que compõem o perfil da cultura organizacional da empresa (estilo de gestão, planos estratégicos, clima, sistema de remuneração, mecanismos de vinculação, liderança e premissas básicas na empresa). A análise leva à comparação entre o estado esperado e o estado atual. O resultado do estado atual é caracterizado pelo perfil dominante da cultura organizacional na empresa, enquanto o resultado do estado esperado fornece informações sobre as preferências e expectativas dos colaboradores em relação ao perfil dominante da cultura organizacional almejada na empresa. Foi falso que o estado atual nas pequenas empresas manufatureiras, de serviços, comércio e empresas mistas é caracterizado com um perfil de cultura de mercado com elementos de cultura organizacional de hierarquia, enquanto o estado esperado é caracterizado com perfil de cultura de clã com elementos de adhocracia, cultura organizacional de mercado e hierarquia.

Palavras-chave: cultura organizacional, pequenas empresas, PME, gestão da segurança,

\section{Resumen}

Este artículo presenta los resultados de una investigación basada en el cuestionario de Cammeron y Quinn. La investigación se llevó a cabo entre empleados de pequeñas empresas con diversos perfiles comerciales. Se evaluaron los elementos que conforman el perfil de la cultura organizacional en la empresa (estilo de gestión, planes estratégicos, ambiente, sistema de remuneración, mecanismos de vinculación, liderazgo y supuestos básicos en la empresa). El análisis conduce a la comparación entre el estado esperado y el estado actual. El resultado del estado actual se caracteriza por el perfil dominante de cultura organizacional en la empresa, mientras que el resultado del estado esperado brinda información sobre las preferencias y expectativas de los empleados en relación al perfil 
dominante de cultura organizacional deseado en la empresa. Se constató que el estado actual en las pequeñas empresas manufactureras, de servicios, comerciales y mixtas se caracteriza por un perfil de cultura de mercado con elementos de cultura organizacional jerárquica, mientras que el estado esperado se caracteriza por un perfil de cultura de clan con elementos de adhocracia, cultura organizacional de mercado y jerarquía.

Palabras clave: cultura organizacional, pequeñas empresas, PYME, gestión de la seguridad,

\section{INTRODUCTION AND LITERATURE REVIEW}

The organizational culture largely depends on the management principles prevailing in individual groups of enterprises. Thus, the structure as well as the composition of many cultures is a reflection of conscious management in a company. At the same time, it should not be forgotten that the greatest capital of every enterprise is human capital, which influences the shaping of cultural relations, but also strongly receives the stimuli of organizational culture. Assuming that the culture of the organization (similarly to the culture of work safety) is closely related to constructive management, dissemination of knowledge and motivating to appropriate actions, it is therefore responsible for shaping safe behavior.

\subsection{Meaning and definition of organizational culture in literature}

In the literature on business management, there are many attempts to define the organizational culture (Frăticiu, Mihăescu, \& Andănuţ, 2015; Schein, 2016, 2018, 2019) There are many disputes between researchers regarding the accuracy and completeness of the definition of organizational culture. Some assume that the organization is culture in itself, others that culture exists in the organization. The sources of culture origin are defined as follows:

- values, customs, religion, norms, patterns of behavior, symbols;

- invisible forces that drive an organization's performance;

- a whole system of meanings, guidelines and directives that mobilize all members of the organization;

- a system of mechanisms controlling behavior in the organization. 
In some ways the enterprise culture is treat only as a concept, in line with the concept that culture is created in human thoughts and only the human (worker) gives it meaning. EH Schein (Schein, 2018) described organizational culture as "a pattern of shared basic assumptions that the group learned as it solved its problems of external adaptation and internal integration, that has worked well enough to be considered valid and, therefore, to be taught to new members as the correct way to perceive, think, and feel in relation to those problems" (Schein, 2018). According to the concepts, that the organizational culture differ depends on whether they relate to the way of acting or thinking. The first orientation is presented in the literature on the subject by M. Bower, who defines culture as "a way of doing things that surround us". Geertz's definition of organizational culture is the position of understanding culture as thinking, and it reads as follows: "(...) it is the production of meanings from which human beings derive their experience and models in action" (Geertz, 1973).

Organizational culture may or may not be valued. In the absence of evaluation, it cannot be said whether the organizational culture is good, bad, low or high. One can only say that it is more or less visible in the organization. The approach that evaluates organizational culture is more popular and dominant. The numerical determination of the organizational culture level additionally allows to observe the improvement or deterioration trends. C. B. Handy proposed that the concept of organizational culture be related to the set of cultural patterns that influence the efficient operation of an organization (Handy, 1987). There is some assumption, that the organizational culture should be measured by the degree to which the existing hierarchy of formal goals of the company is reflected in the awareness and actions of all members of the organization. In terms of managing an organization, an approach that evaluates organizational culture becomes indispensable. Then one should adopt the principle that the organizational culture can be bad, good, high, low, negative, positive, edifying, destructive, etc. As Cameron and Quinn $(20111,2014)$ wrote, there is no ideal model of organizational culture. And only the organization itself can develop the best, characteristic model, profile (Cameron \& Quinn, 2011; Cameron, Quinn, Degraff, \& Thakor, 2014). 


\subsection{Human-worker and organizational culture}

When analyzing various proposed definitions of organizational culture, it can be assumed, that "it is a system of patterns of thinking and acting informally established in the social environment of the organization, which are significant for the implementation of formal organizational goals". The effectiveness of the enterprise with its organizational culture was first linked by G. Hofstede (Aniszewska, 2004). In turn, Cameron and Quinn believe that the organizational culture has been disregarded and downplayed by management theorists and practitioners for many years. They provide examples of profiles of over 1000 companies, which often serve as a benchmark for comparison and possible diagnosis of changes. The authors describe employers and supervisors in terms of each of the four profiles of culture - adhocracy, clan, hierarchy and market (Cameron et al., 2014). Some literature - contrary to many researchers - provide a "recipe" for an ideal organizational culture. It should include "a little entrepreneurship, a little bureaucracy (...) saturation with innovation (...) intensification with a social atmosphere sufficient to satisfy the expectations of employees who want to know why they should engage in work". This is confirmed by the research presented in numerous scientific publications (Niciejewska \& Ślęzak-Jasik, 2015; Niciejewska \& Zyska, 2015; Nováková, Šujanová, \& Nováková, 2019). The most desirable profile of organizational culture in enterprises is usually a model with a similar intensity of market culture, adhocracy, hierarchy with a slight dominance of the clan culture. Such a general model of organizational culture causes, inter alia, that the "climate" in the company relieves unhealthy tensions that prevail both between the employer and employees as well as between the employees themselves (Chan, 1997; Tseng, 2010).

However, it should be remembered that the organizational culture model is determined by such features of the enterprise as the industry and the size of the economic entity. According to the literature on the subject, organizational culture is closely related to the greatest potential and capital of any organization - human (Abdullah, Khalizani, Fatima Mohsen, \&., 2019; Chatman \& O’Reilly, 2016; Knein, Greven, Bendig, \& Brettel, 2020; Nazarian, Atkinson, \& Foroudi, 2017). Numerous studies indicate the role that organizational culture plays in relation to the behavior of human capital. It has a positive effect on the attitudes and behavior of employees. It should be remembered that they (these attitudes and behaviors) have long been the main cause of reported accidents at work and occupational diseases (Aniszewska, 2004; Cameron \& Quinn, 2011; Serrat; Silla, Navajas, \& Koves, 2017). It is the organizational culture that is the basis of the culture of work safety, 
distinguished by science, being its autonomous part. Based on the concept of Knowledge Management, it is also assumed that the culture of an organization has a great influence on the information flows and the dispersion of knowledge. Therefore, it should be stated that the learning and communication processes of employees are the most variable factors in shaping the organizational culture (Criado-García, Calvo-Mora, \& Martelo-Landroguez, 2019; Klimecka-Tatar \& Ingaldi, 2020; Paliszkiewicz, Svanadze, \& Jikia, 2017; Tseng, 2010). It is known that knowledge, method of communication, training and motivation are the most important elements shaping safe working conditions (apart from the aspect of technical maintenance of safety). Caring for the appropriate organizational culture, creating conditions for appropriate employee behavior is the key to safe and hygienic working conditions (Matuszny, 2020; Stachová, Stacho, Papulová, \& Jemala, 2019; Zaloga, Dyadyura, Rybalka, Pandova, \& Zaborowski, 2020). Knowledge management, moderating the organizational culture and building awareness of a safe work environment allow and help prevent accidents. Constructive cultures support safe working conditions. The relationship between culture and conscious occupational safety also affects employee satisfaction (Silla et al., 2017).

Culture defined in the area of occupational health and safety is one of the organizational culture elements. Therefore it should be treated as inseparable elements. Organizational culture helps in the culture of health and safety management and contributes to raises the level of health and safety in enterprises (Isensee, Teuteberg, Griese, \& Topi, 2020; Kapusta, Sukiennik, \& Bąk, 2018).

\section{METHODOLOGY}

Statistical methods were used to analyze the research results. On the other hand, the basis for collecting data for the assessment of the organization's culture was the questionnaire research. As a research tool the questionnaire by Cammeron and Quinn (Cameron \& Quinn, 2011) was used. The questionnaire by Cammeron and Quinn is based on the evaluation of individual elements that make up the profile of the organizational culture in the company. During the analysis in individual profiles of the organization, such features as: management style, strategic plans, atmosphere, remuneration system, bonding mechanisms, leadership and basic assumptions in the company. The respondents evaluate these features by assigning a total of 100 points both in the "current state" (prevailing in the 
company) and the expected state (under which conditions they would like to work). The analysis consists in comparing the expected state with the present one and drawing conclusions about potential changes that need to be made in the company. Data - with the use of a questionnaire - were obtained in the period from January 2012. Almost 3,150 questionnaires were sent electronically. As a result of the attempts to obtain feedback from randomly selected enterprises, almost 1,800 questionnaires were collected, of which over 700 were not suitable for analysis. After the survey questionnaires were verified, 1006 complete and correctly completed questionnaires were finally allocated to the analysis and evaluation of the obtained answers. It should be noted that only one questionnaire was collected from each economic entity, so the number of respondents is equal to the number of surveyed economic entities. Only "small-sized" enterprises - micro (1-9 employees) and small enterprises (10-49 employees) were selected for the study.

The data was presented in an ordinal and nominal scale. Mainly, the structure indexes, correlation analysis with the use of the tau-Kendall coefficient, and the independence test $\chi^{2}$ and the correlation coefficient $\varphi$-Youl were used. In the case of small sample sizes, the Yates correction was additionally used. In the field of mathematical statistics, the Mann-Whitney test was used as an alternative to the mean test. The calculations and graphic illustrations were made using the Excel spreadsheet and the Statistica 12 statistical package.

\section{RESULTS AND DISCUSSION}

\subsection{Respondents characteristic}

As a result of the survey, answers were obtained from economic entities, according to the following sectors:

- $\quad$ trade (4\% from the surveyed group of economic entities),

- $\quad$ mixed (14\% from the surveyed group of economic entities),

- $\quad$ production (24\% from the surveyed group of economic entities)

- $\quad$ service (58\% of the studied group of business entities).

Thus, the highest number of correctly completed questionnaires were obtained from service enterprises. In addition, the largest number of questionnaires (55\% of all obtained questionnaires) came from the smallest business entities, with 1 to 9 employees, i.e. microenterprises. 
Almost every fifth respondent who completed the questionnaire answering questions on selected health and safety issues is an employee 22-34 years old. Every third employee who answered the questions was 45-54 years old. Only 7\% of the youngest employees (1824 years old) and 3.6\% of the oldest employees (56-64 years old and 65 and more) took part in the study.

The respondents are employees with 6-10 years of work experience (almost every third respondent). The least numerous group of respondents were employees with the greatest work experience (16-20 years - 2.5\%, 21-25 years - $1.5 \%$ and 26 years and more $1.4 \%)$. Moreover, a much larger number of respondents were employees with low work experience (up to 10 years of work experience).

According to the questionnaires, the most common type of work performed among the respondents was manual work (78\%). Only every 10th respondent performed intellectual or mixed work. Employees with secondary (41\%) and vocational education (36\%) dominated among the respondents. Every fifth respondent had higher education. Only $1 \%$ of the surveyed employees had basic education. Most of the respondents were men (as much as $72 \%$ ). The work of the respondents was rather team work, only every 4th respondent declared individual work. The overwhelming majority $(87 \%)$ of respondents who answered the questions in the questionnaire, were employed in a given economic entity, but were not owners. On the other hand, almost every 5th respondent declared being the owner of the company.

\subsection{Assessment of the organization's culture}

Based on the questions contained in the questionnaire developed by Cammeron and Quinn, data was collected about: criteria for the success of the organization, emphasis on various factors, the consistency of the organization, the way of management, the leadership of the organization and the overall characteristics of the organization.

On the basis of the structure of respondents' answers, it is possible to assess both the current state (CS) and the expected state (ES) of the organizational culture of "small-sized" enterprises". Figure 1 presents the results concerning the current state of organizational culture in manufacturing companies. Whereas, expected state of organizational culture in manufacturing companies is presented in Figure 2. 


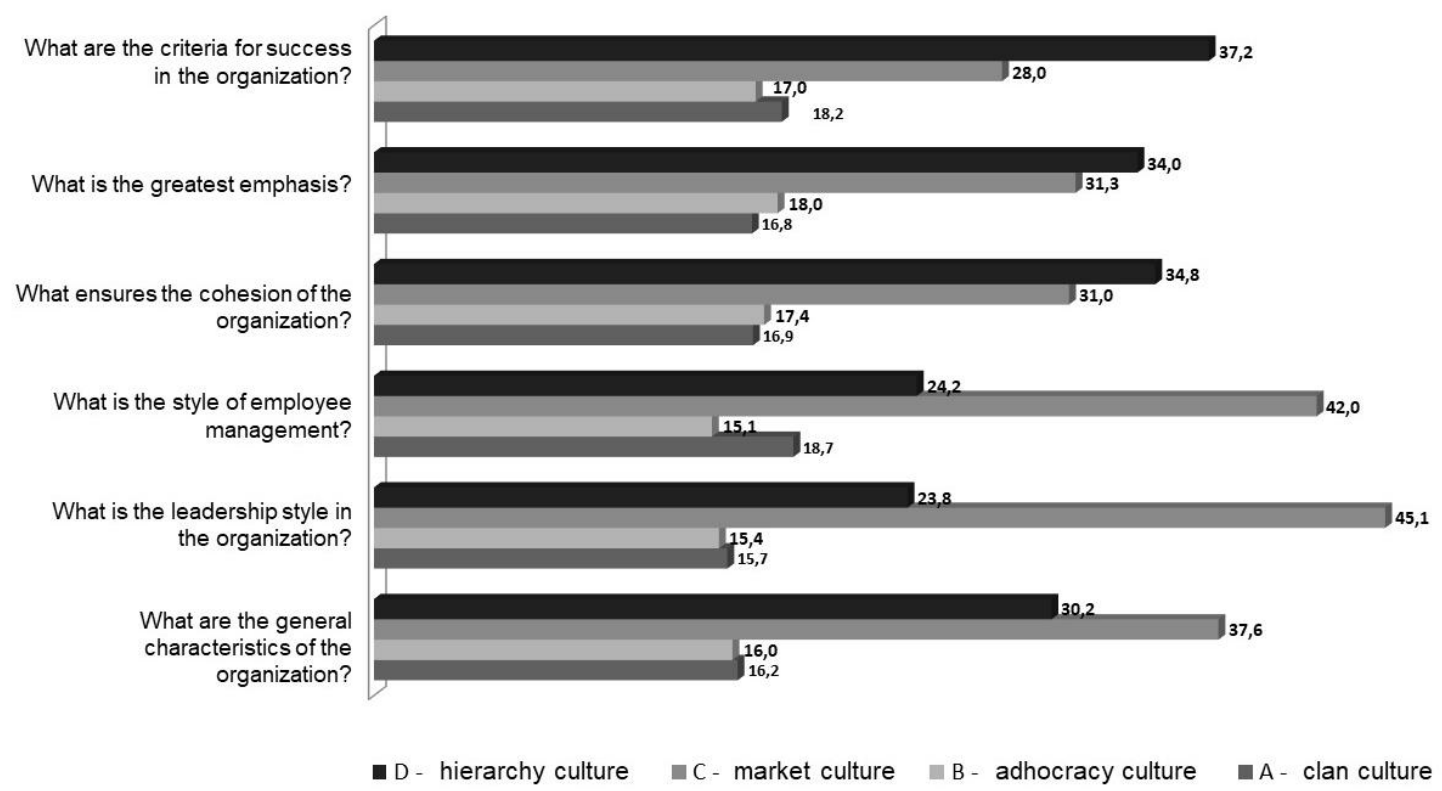

Figura. 1. The current state (CS) of organizational culture in manufacturing enterprises (based on a questionnaire developed by Cammeron and Quinn) - own study

In the opinion of the respondents - employees of production enterprises - the current state (CS) of organizational culture is a market culture with elements of hierarchy culture. The expected state (ES) of organizational culture in production companies (in which employees would like to work), in the opinion of respondents, is the culture of the clan, with simultaneous interference with the features of other cultures: the market, adhocracy and hierarchy. The above trends are presented in the collective figure 3.

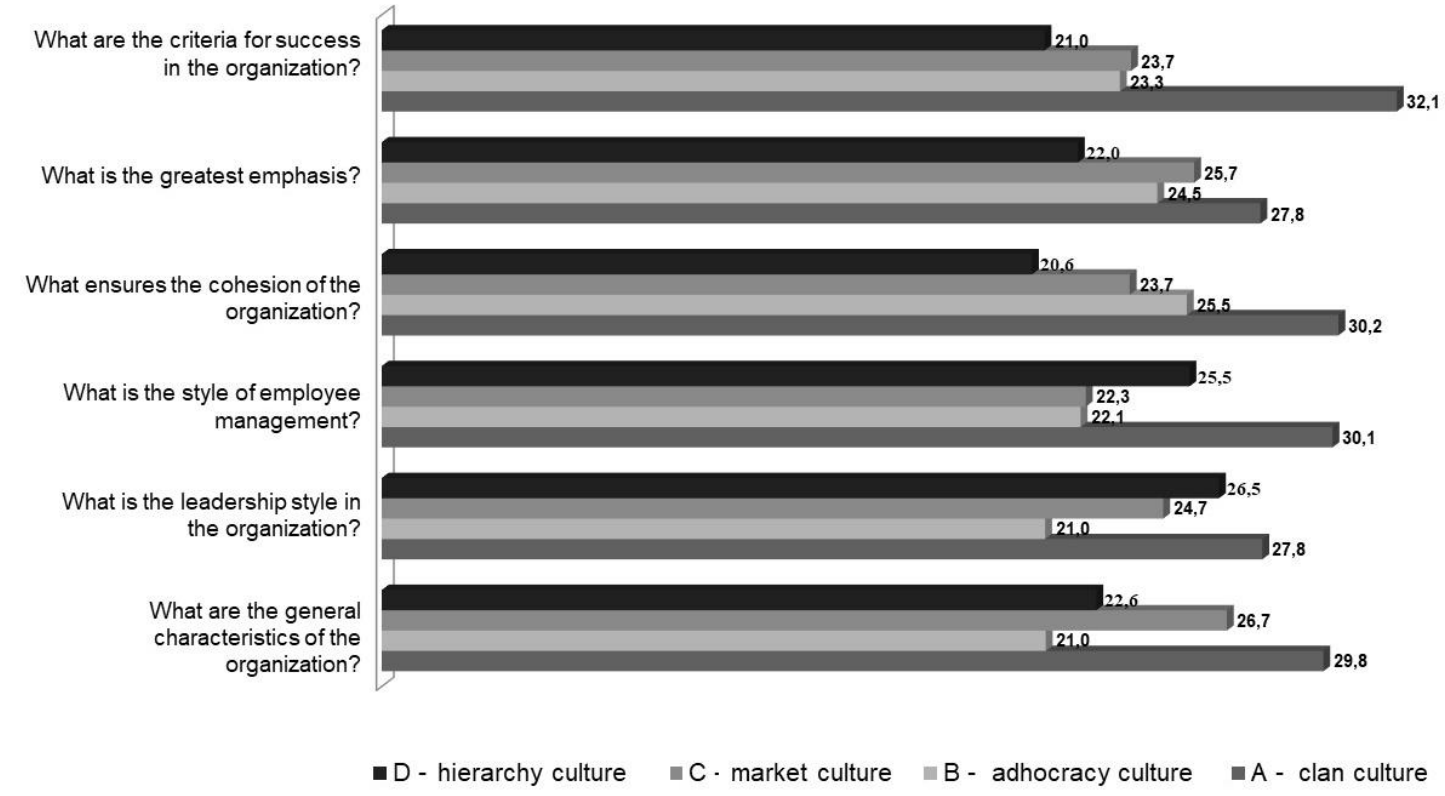

Figura 2- The expected state (ES) of organizational culture in manufacturing enterprises (based on a questionnaire developed by Cammeron and Quinn) - own study 
The results regarding the current state (CS) and the organizational culture expected (ES) by employees are included in table 1.

Table 1

Profile of organizational culture in manufacturing enterprises - own study

\begin{tabular}{|l|c|c|}
\cline { 2 - 3 } \multicolumn{1}{c|}{} & $\begin{array}{c}\text { Current state } \\
\text { (CS) }\end{array}$ & $\begin{array}{c}\text { Expected state, } \\
\text { (ES) }\end{array}$ \\
\hline A - clan culture & $17.08 \%$ & $29.63 \%$ \\
\hline B - culture of adhocracy & $16.45 \%$ & $22.90 \%$ \\
\hline C - market culture & $35.80 \%$ & $24.45 \%$ \\
\hline D - hierarchy culture & $30.67 \%$ & $23.02 \%$ \\
\hline Summary: & $100.00 \%$ & $100.00 \%$ \\
\hline
\end{tabular}

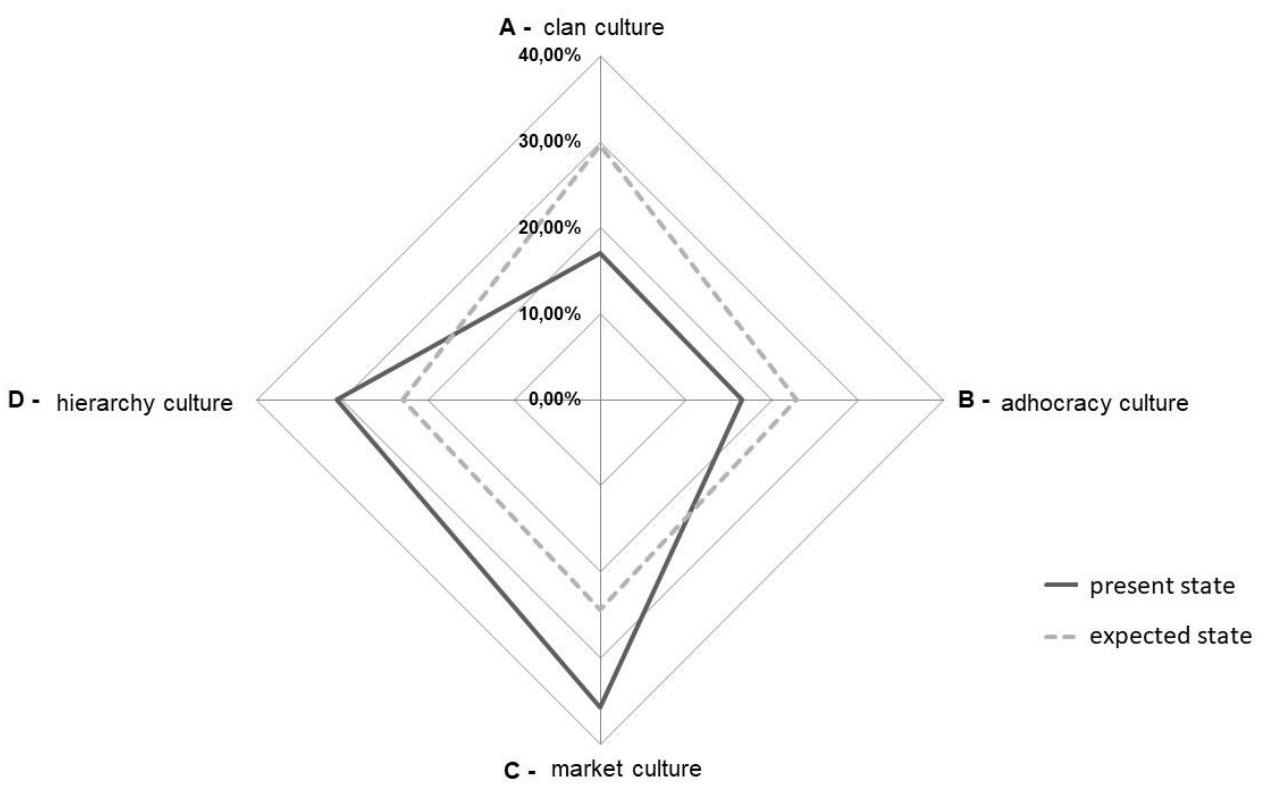

Figura. 3 -Profile of organizational culture in manufacturing enterprises - own study

It is obvious that the presented profile of organizational culture is a market culture with elements of hierarchy culture. Manufacturing companies are characterized by strictly established procedures, rules for performing tasks related to production, and the time allocated to the production process. Maintaining the market is the priority of every enterprise. The hierarchy culture, in turn, results from the nature of the industry. Expected state, the so-called "the wishful" profile of organizational culture in manufacturing 
enterprises comes as no surprise. An organization with a clan culture is a family organization, characterized by a high degree of participation and cohesion. Work in such a climate is desired by almost every employee. It is assumed that the factors of an organization's business success are placed in creating the culture and structural features of a clan organization. Clan organizations can create a more manageable social space that provides stability. The clan structure and its organizational principles guide strategic management in a changing and dynamic environment - which is in line with the literature (Chan, 1997).

The current state of organizational culture in service enterprises, in the opinion of the respondents, is shaped by the features - similarly to manufacturing enterprises - of market culture with elements of hierarchy culture - Figure 4. The expected state of the organizational culture of service enterprises in the opinion of the respondents is presented in Figure 5.

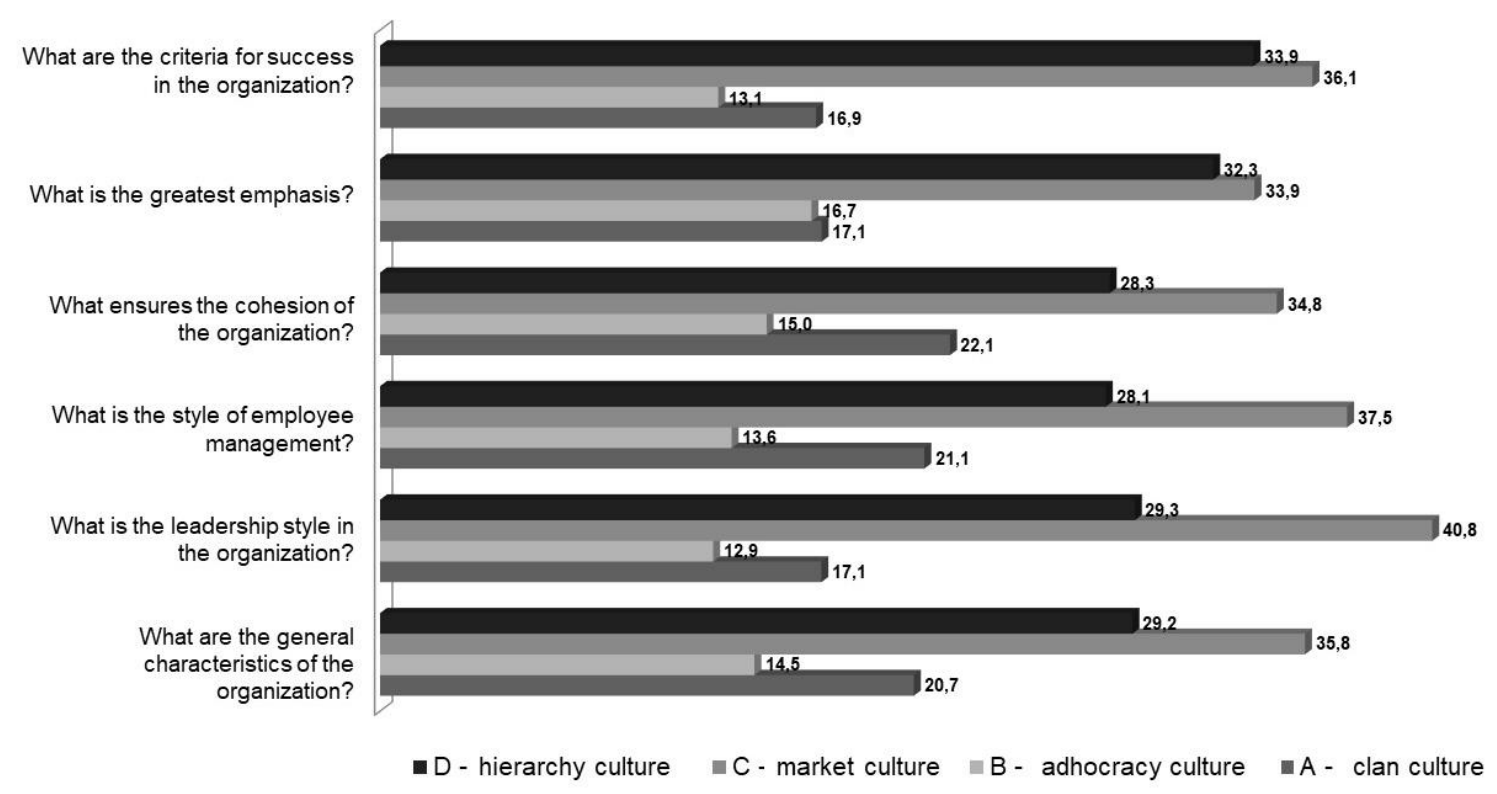

Figura 4- The current state of organizational culture in service enterprises (based on a questionnaire developed by Cammeron and Quinn) - own study 


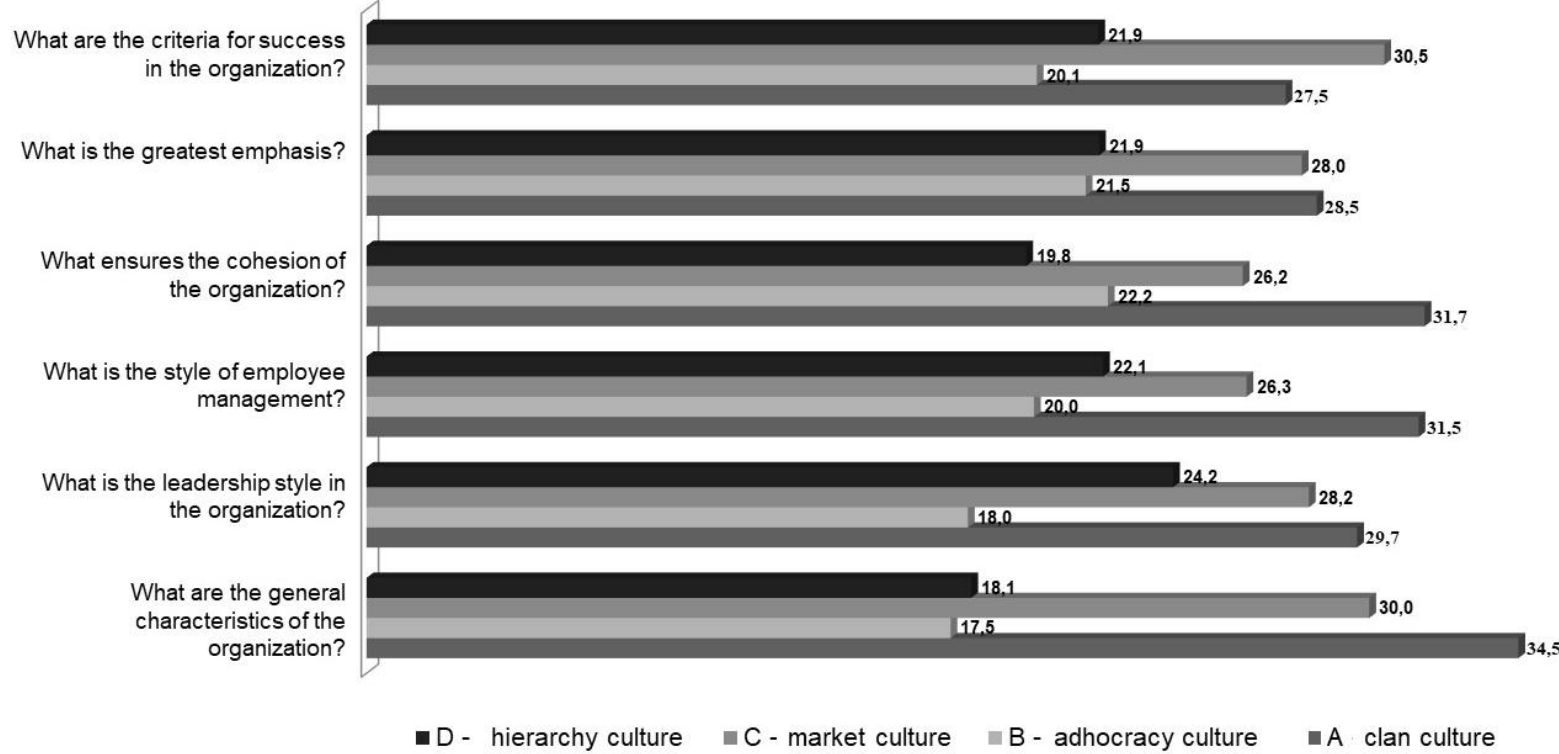

Figura. 5- The expected state of organizational culture in service enterprises (based on a questionnaire developed by Cammeron and Quinn) - own study

Table 2 shows the percentage structure necessary to estimate the culture profile of the service enterprises.

\section{Table 2}

Profile of organizational culture in service enterprises - own study

\begin{tabular}{|l|c|c|}
\cline { 2 - 3 } \multicolumn{1}{c|}{} & $\begin{array}{c}\text { Current state } \\
\text { (CS) }\end{array}$ & $\begin{array}{c}\text { Expected state } \\
\text { (ES) }\end{array}$ \\
\hline A - clan culture & $19.14 \%$ & $30.56 \%$ \\
\hline B - culture of adhocracy & $14.29 \%$ & $19.89 \%$ \\
\hline C - market culture & $36.44 \%$ & $28.23 \%$ \\
\hline D - hierarchy culture & $30.13 \%$ & $21.33 \%$ \\
\hline Summary: & $100.00 \%$ & $100.00 \%$ \\
\hline
\end{tabular}

Comparision of the results in the light of the current and expected state of organizational culture in service enterprises based on the opinion of the respondents is presented in Fig. 6 
D - hierarchy culture

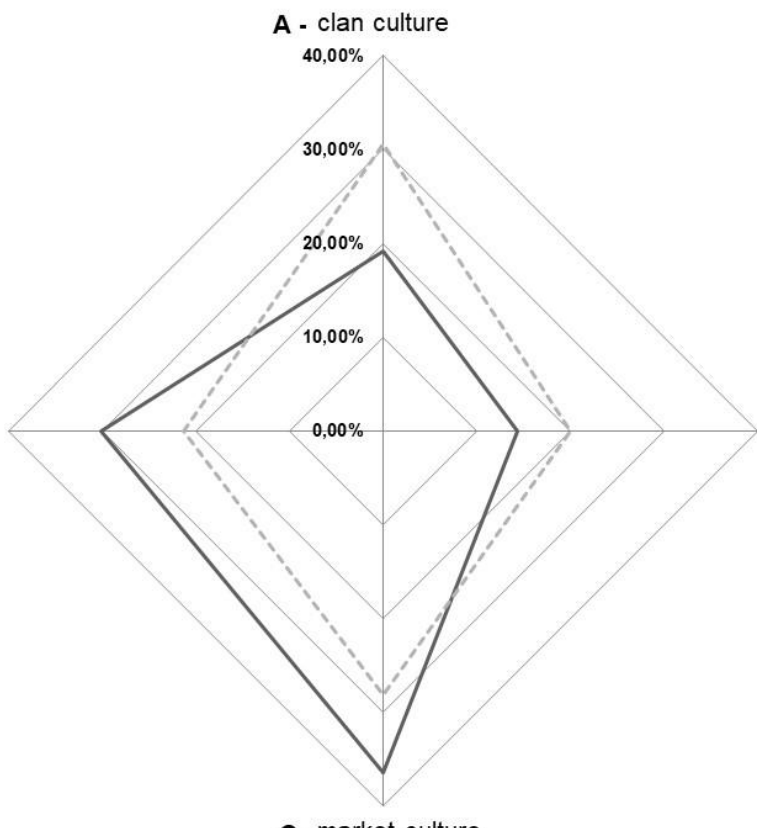

B - adhocracy culture

— present state

-... expected state

C market culture

Figura. 6- Profile of organizational culture in service enterprises - own study

It is clear that the current state of organizational culture - market culture with elements of hierarchical culture - is not the climate in which employees want to work. The expected profile of organizational culture is the culture of the clan with elements of market culture. Clan culture positively moderates the effect of customer incivility (Balaji, Jiang, Singh, \& Jha, 2020). Figures 7 and 8 present the current state and the expected state of organizational culture in trade enterprises in the opinion of the respondents.

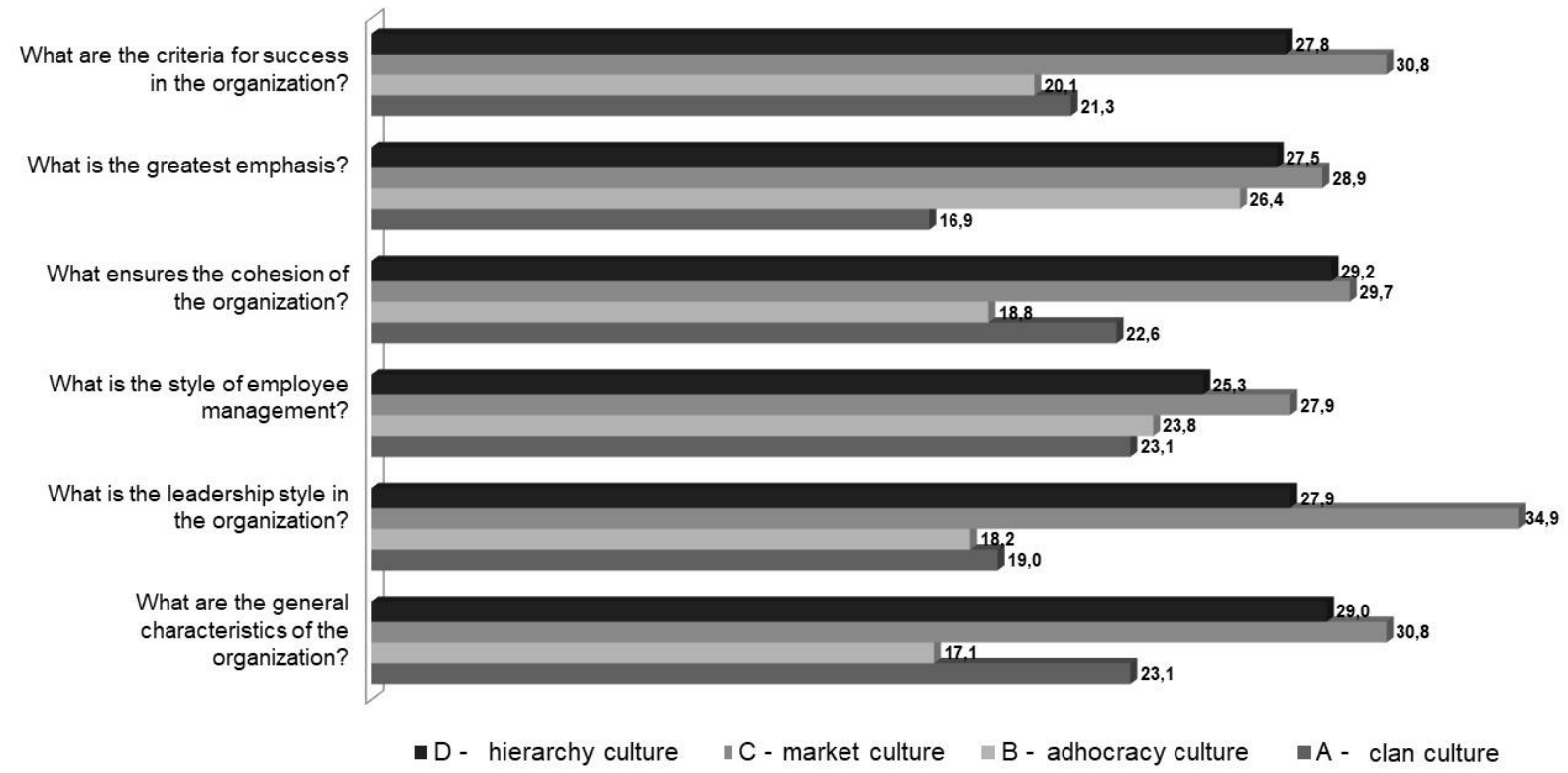

Figura 7- The current state of organizational culture in trade enterprises (based on a questionnaire developed by Cammeron and Quinn) - own study 


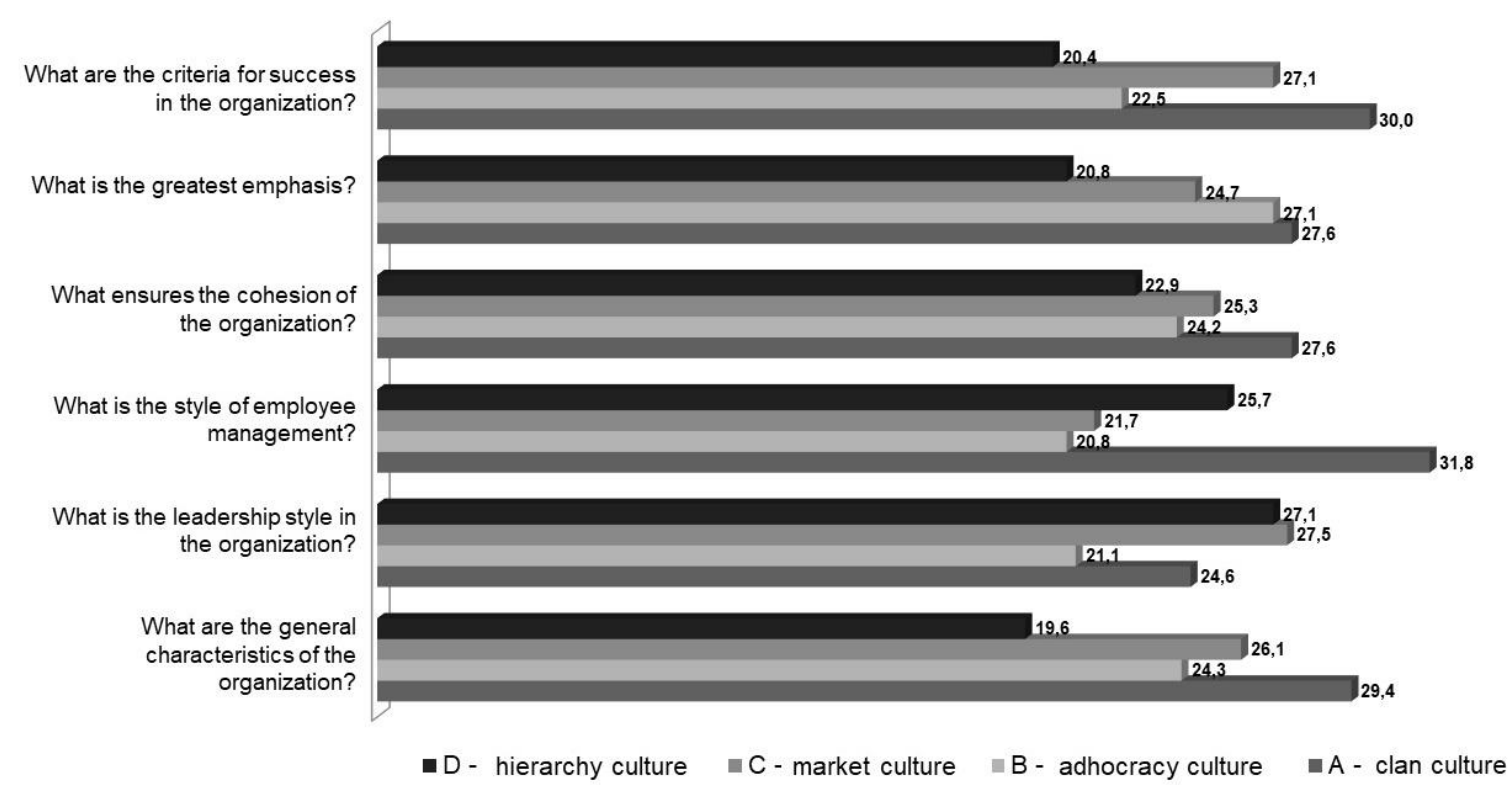

Figura 8- The expected state of organizational culture in trade enterprises (based on a questionnaire developed by Cammeron and Quinn) - own study

Table 3 shows the percentage structure necessary to estimate the culture profile of the trade enterprises, Wheras, Figure 9 presents the comparison of the organizational culture current and expected state in trade enterprises in the respondents' opinion.

\section{Table 3}

Profile of organizational culture in trade enterprises - own study

\begin{tabular}{|l|c|c|}
\cline { 2 - 3 } \multicolumn{1}{c|}{} & $\begin{array}{c}\text { Current state } \\
\text { (CS) }\end{array}$ & $\begin{array}{c}\text { Expected state } \\
\text { (ES) }\end{array}$ \\
\hline A - clan culture & $20.99 \%$ & $28.52 \%$ \\
\hline B - culture of adhocracy & $20.72 \%$ & $23.33 \%$ \\
\hline C - market culture & $30.51 \%$ & $25.39 \%$ \\
\hline D - hierarchy culture & $27.78 \%$ & $22.75 \%$ \\
\hline Summary: & $100.00 \%$ & $100.00 \%$ \\
\hline
\end{tabular}




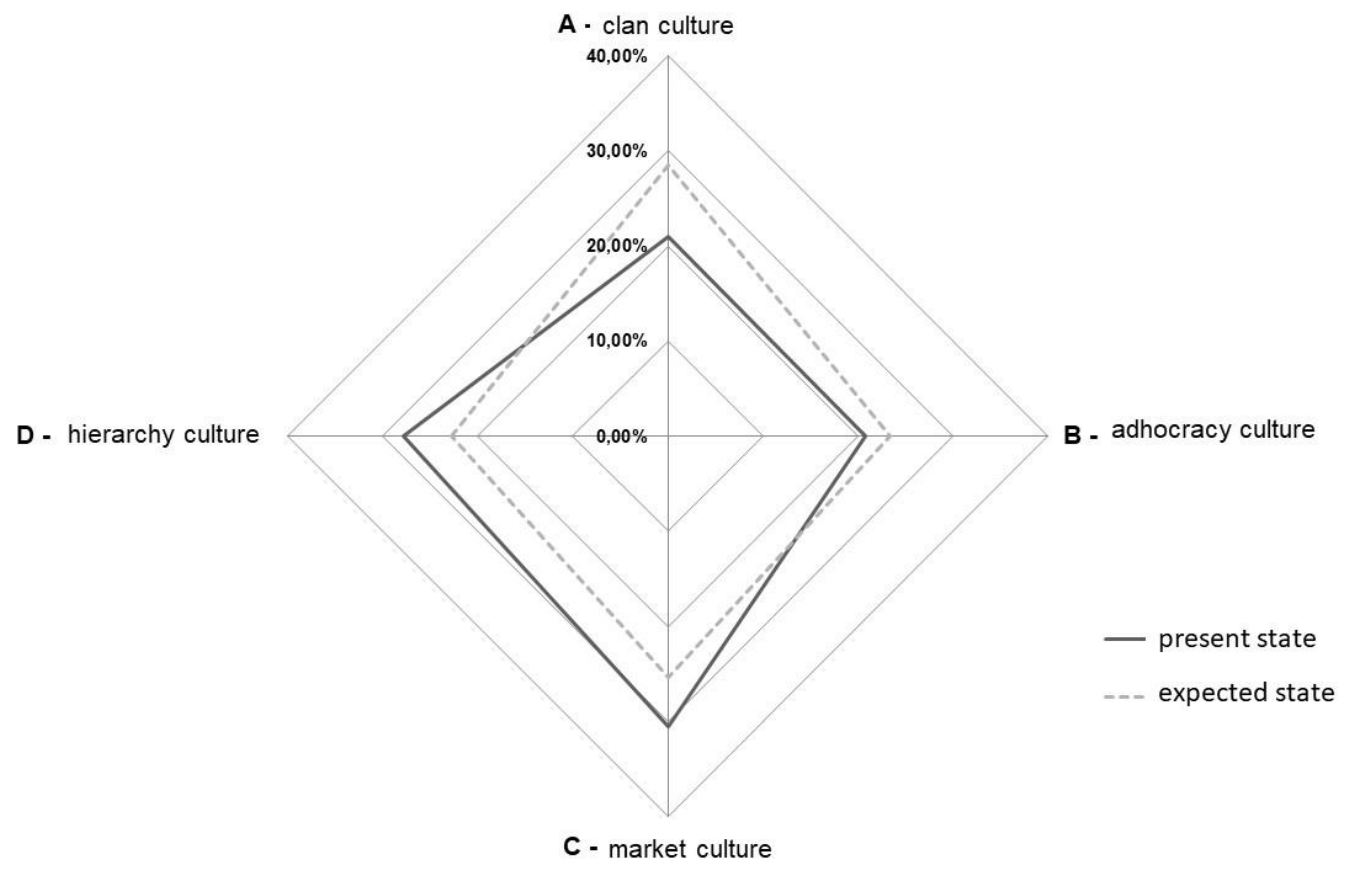

Figura 9.- Profile of organizational culture in trade enterprises - own study

According to the respondents, the current state of the organizational culture profile is market culture with elements of hierarchy. The expected profile of the organizational culture is the culture of the clan with elements of adhocracy, market and hierarchy.

Then, the current state and the desired profile of the organizational culture of mixed enterprises was examined in the opinion of the respondents. The results are presented in Figures 10 and 11. 


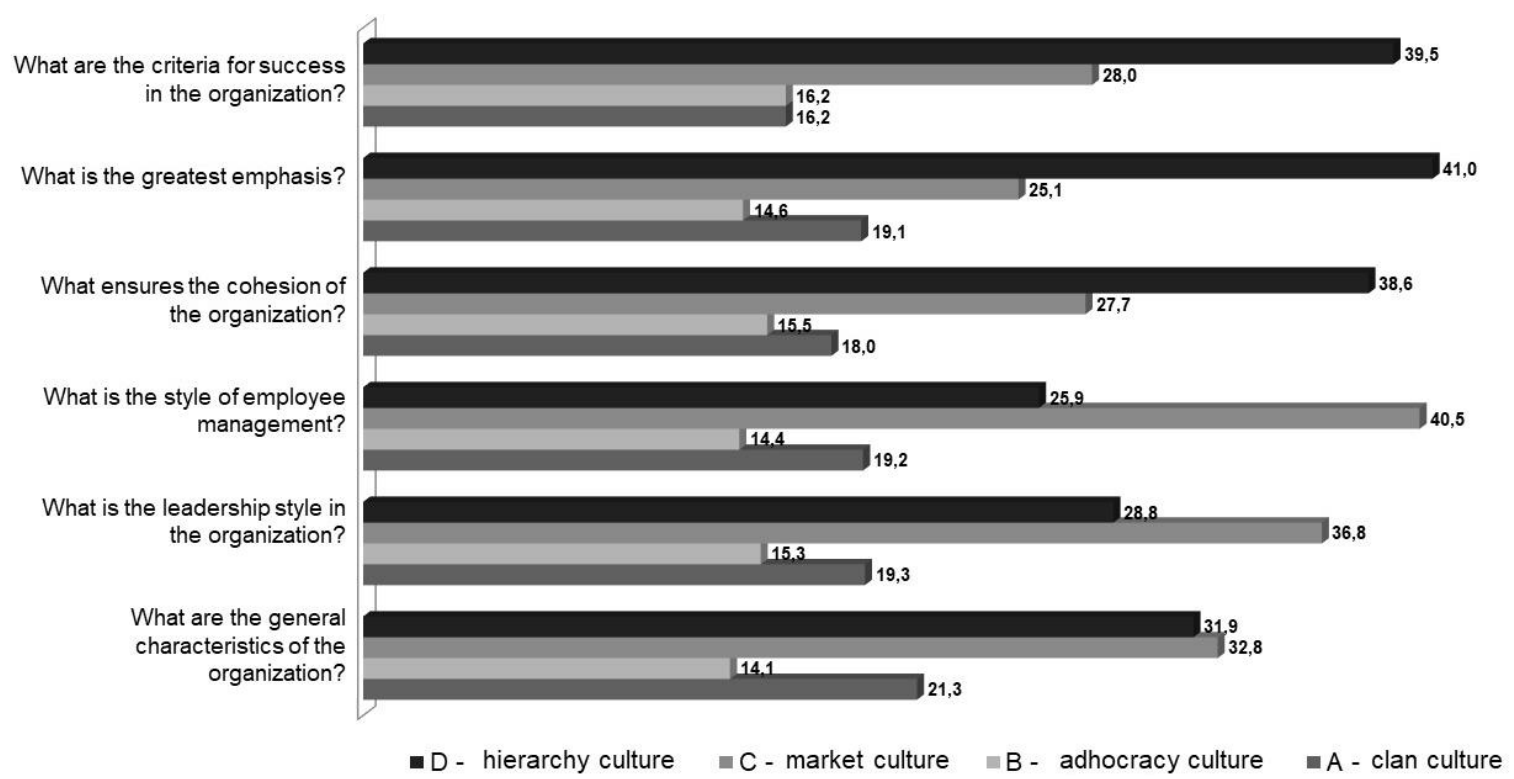

Figura 10- The current state of organizational culture in mixed enterprises (based on a questionnaire developed by Cammeron and Quinn) - own study

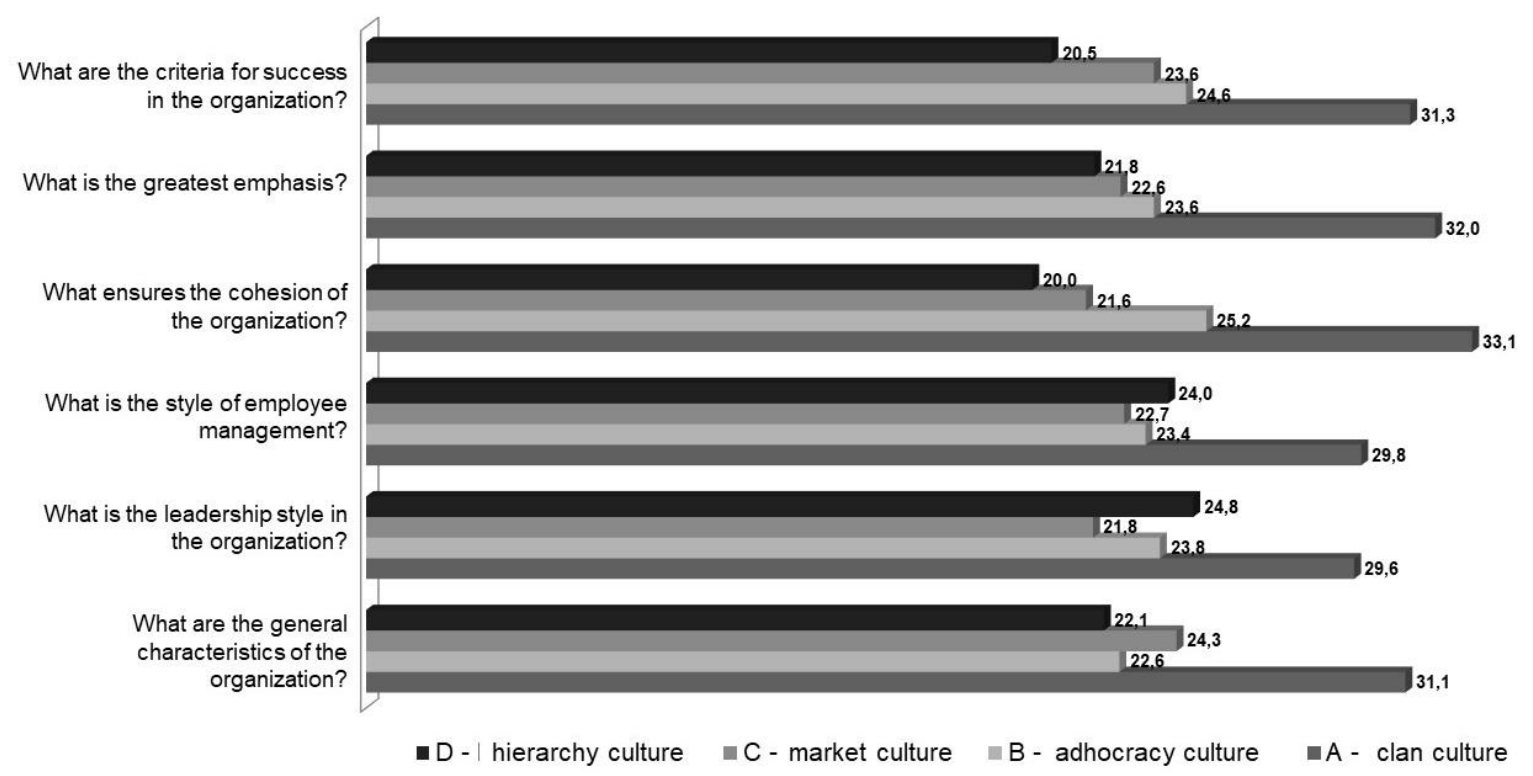

Figura 11- The expected state of organizational culture in mixed enterprises (based on a questionnaire developed by Cammeron and Quinn) - own study

The differences that exist between the current state and the expected profile of the organizational culture of mixed enterprises in the opinion of the respondents are presented in Table 4 and Figure 12. 


\section{Table 4}

Profile of organizational culture in mixed enterprises

\begin{tabular}{|l|c|c|}
\cline { 2 - 3 } \multicolumn{1}{c|}{} & $\begin{array}{c}\text { Current state } \\
\text { (CS) }\end{array}$ & $\begin{array}{c}\text { Expected state } \\
\text { (ES) }\end{array}$ \\
\hline A - clan culture & $18.84 \%$ & $31.18 \%$ \\
\hline B - culture of adhocracy & $15.02 \%$ & $23.85 \%$ \\
\hline C - market culture & $31.84 \%$ & $22.76 \%$ \\
\hline D - hierarchy culture & $34.31 \%$ & $22.21 \%$ \\
\hline Summary: & $100.00 \%$ & $100.00 \%$ \\
\hline
\end{tabular}

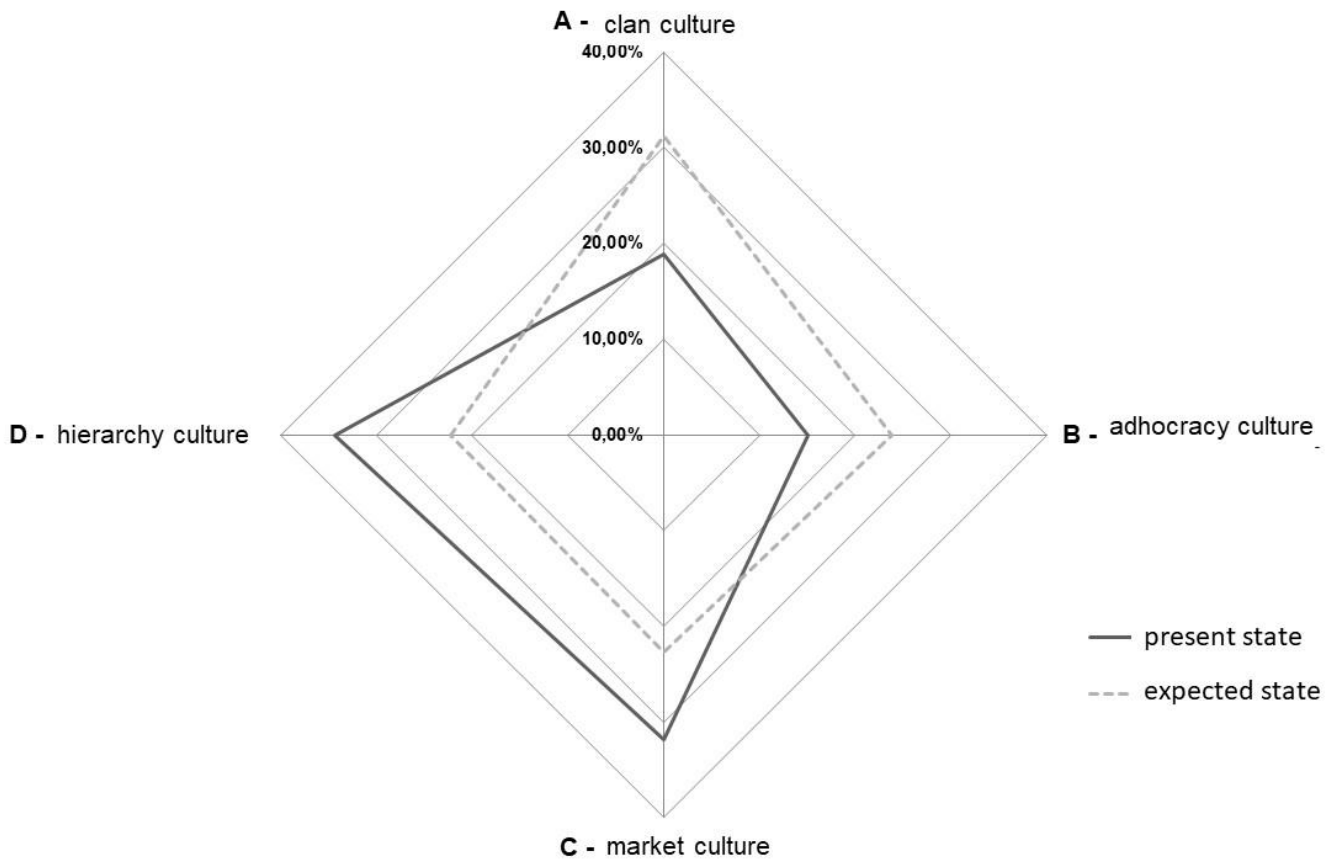

Figura 12- Profile of organizational culture in mixed enterprises - own study

In the opinion of the respondents - employees of mixed enterprises - the current state of the organizational culture profile is a strong hierarchy culture with an equally strong emphasis on market culture. The expected state of the organizational culture profile of mixed enterprises this time differs significantly from the current state. The respondents would like to work in conditions that would be shaped by the culture of the clan and adhocracy, with little interference from other cultures - the market and hierarchy.

Table 5 presents the values of the structure similarity coefficients for the profile of organizational culture depending on the sector of activity of enterprises. 
Table 5

Values of the structure similarity coefficients for the profiles of organizational culture depending on the sector of the enterprise's activity - own study

\begin{tabular}{|l|l|c|c|c|}
\hline \multicolumn{1}{|c|}{ State } & \multicolumn{1}{|c|}{ Sector } & service & trade & mixed \\
\hline \multirow{3}{*}{$\begin{array}{l}\text { Current } \\
\text { (CS) }\end{array}$} & manufacturing & $97.3 \%$ & $91.8 \%$ & $94.6 \%$ \\
\cline { 2 - 3 } & service & & $91.7 \%$ & $95.1 \%$ \\
\cline { 2 - 3 } & trade & & & $92.1 \%$ \\
\hline \multirow{3}{*}{$\begin{array}{l}\text { Expected } \\
\text { (ES) }\end{array}$} & manufacturing & $95.3 \%$ & $98.6 \%$ & $97.5 \%$ \\
\cline { 2 - 3 } & service & & $95.1 \%$ & $94.5 \%$ \\
\cline { 2 - 2 } & trade & & $96.8 \%$ \\
\hline
\end{tabular}

As follows from the presented results, enterprises do not differ significantly in terms of their organizational culture profile. There is, however, a gap between what is expected and what is today, and it is much higher, especially in mixed-activity enterprises. Most enterprises with up to 9 employees (micro enterprises) have loose, informal relations between the supervisor (employer) and employees. The climate in micro-enterprises resembles that in the family, therefore the organizational culture in the surveyed enterprises with up to 9 employees can be described as a clan culture with evident elements of market culture (fight for customers, competitiveness and staying on the market).

In small enterprises of 10 to 49 employees, the organizational culture is more like a market culture with strong elements of an adhocracy culture. The elements of clan culture are not as strong in small enterprises as they are in micro enterprises. Relationships between employees, managers and superiors are more formalized and the hierarchy prevailing and binding is felt. There is no strong discrepancy between the expected state and the current state of organizational culture in the "small size" companies surveyed. Employees do not show the desire for major changes in the relations between them and their superiors, and do not seem dissatisfied with the current climate in their workplaces. As it results from the research conducted among employees of small-sized enterprises, the current state of organizational culture does not differ much from the expected state, although the majority appreciate the relationship-friendly climate, without rigid framework and hierarchy. Of course, there are such forms of enterprises in which these undesirable, rigid relationships and hierarchy constitute the basis for their operation, but the vast majority of the surveyed enterprises see great value in a relationship-friendly climate that affects the quality, efficiency and safety of work. The questionnaire by Cammeron and Quinn is based on the evaluation of individual elements that make up the profile of the organizational culture in 
the company. During the analysis in individual profiles of the organization, such features as: management style, strategic plans, atmosphere, remuneration system, bonding mechanisms, leadership and basic assumptions in the company. An ideal profile of organizational culture in a company is considered to be one that has some of the culture of the clan, market, adhocracy (development orientation) and hierarchy. The organizational culture (climate) of the enterprise significantly influences the safety of work in enterprises of "small size". Further research by the team will refer to in-depth research on the state of occupational safety in relation to the current state of organizational culture.

\section{CONCLUSIONS}

As it results from the research conducted among employees of small-sized enterprises, the current state of organizational culture does not differ much from the expected state, although the majority appreciate a relationship-friendly climate, without rigid framework and hierarchy. On the basis of the obtained results it was found that:

- the present state in the small-sized manufacturing, service, trade and mixed enterprises is characterized with profile of market culture with elements of hierarchy organizational culture,

- expected state in the small-sized manufacturing, service, trade and mixed enterprises is characterized with profile of clan culture with elements of adhocracy, market and hierarchy organizational culture.

\section{REFERENCES}

Abdullah, O., Khalizani, K., Fatima Mohsen, A., \&. (2019). Exploring the role of safety culture factors towards safety behaviour in small-medium enterprise. International Journal of Entrepreneurship, 23(3), 1-11.

Aniszewska, G. (2004). Rola kultury organizacyjnej w zarządzaniu. Przegląd Organizacji. (1).

Balaji, M. S., Jiang, Y., Singh, G., \& Jha, S. (2020). Letting go or getting back: How organization culture shapes frontline employee response to customer incivility. Journal of Business Research, 111, 1-11. https://doi.org/10.1016/j.jbusres.2020.02.007

Cameron, K. S., \& Quinn, R. E. (2011). Diagnosing and changing organizational culture: Based on the competing values framework: John Wiley \& Sons.

Cameron, K. S., Quinn, R. E., Degraff, J., \& Thakor, A. V. (2014). Competing Values Leadership: Second Edition: New Horizons in Management series: Edward Elgar Publishing. 
Chan, A. (1997). Corporate culture of a clan organization. Management Decision, 35(2), 94 99. https://doi.org/10.1108/00251749710160232

Chatman, J. A., \& O'Reilly, C. A. (2016). Paradigm lost: Reinvigorating the study of organizational culture. Research in Organizational Behavior, 36, 199-224. https://doi.org/10.1016/j.riob.2016.11.004

Criado-García, F., Calvo-Mora, A., \& Martelo-Landroguez, S. (2019). Knowledge management issues in the EFQM excellence model framework. International Journal of Quality \& Reliability Management, 37(5), 781-800. https://doi.org/10.1108/IJQRM-112018-0317

Frăticiu, L., Mihăescu, D., \& Andănuţ, M. (2015). Culture-Civilization-Organizational Culture and Managerial Performance. Procedia Economics and Finance, 27, 69-72. https://doi.org/10.1016/S2212-5671(15)00973-9

Geertz, C. (1973). The Interpretation of Culture. Basic Book.: NEW YORK. New York: Inc., Publishers.

Handy, C. B. (1987). Understanding organizations - Harmondsworth, Middlesex. England, London: Penguin Books Ltd.

Isensee, C., Teuteberg, F., Griese, K.-M., \& Topi, C. (2020). The relationship between organizational culture, sustainability, and digitalization in SMEs: A systematic review. Journal of Cleaner Production, 275, 122944. https://doi.org/10.1016/j.jclepro.2020.122944

Kapusta, M., Sukiennik, M., \& Bąk, P. (2018). Effectiveness of Occupational Health and Safety Rules in Shaping Organizational Culture. Inżynieria Mineralna, 19(1), 245-254.

Klimecka-Tatar, D., \& Ingaldi, M. (2020). How to indicate the areas for improvement in service process - the Knowledge Management and Value Stream Mapping as the crucial elements of the business approach. Revista Gestão \& Tecnologia, 20(2), 52-74. https://doi.org/10.20397/2177-6652/2020.v20i2.1878

Knein, E., Greven, A., Bendig, D., \& Brettel, M. (2020). Culture and cross-functional coopetition: The interplay of organizational and national culture. Journal of International Management, 26(2), 100731. https://doi.org/10.1016/j.intman.2019.100731

Matuszny, M. (2020). Building decision trees based on production knowledge as support in decision-making process. Production Engineering Archives, 26(2), 36-40. https://doi.org/10.30657/pea.2020.26.08

Nazarian, A., Atkinson, P., \& Foroudi, P. (2017). Influence of national culture and balanced organizational culture on the hotel industry's performance. International Journal of Hospitality Management, 63, 22-32. https://doi.org/10.1016/j.ijhm.2017.01.003

Niciejewska, M., \& Ślęzak-Jasik, J. (2015). Znaczenie kultury organizacyjnej w przedsiębiorstwie usługowym: Budujmy wspólnie kulturę bezpieczeństwa, (ed.) W. Babicz, K. Zadros, . Częstochowa: WZPCZ.

Niciejewska, M., \& Zyska, A. (2015). Kultura organizacyjna w publicznym i niepublicznym zakładzie opieki zdrowotnej - analiza porównawcza: Budujmy wspólnie kulture bezpieczeństwa, (ed.) W. Babicz, K. ZAdros, . Częstochowa: WZPCZ. 
Nováková, R., Šujanová, J., \& Nováková, N. (2019). Improving Quality Management - the Way Toward Economic Prosperity and Quality of Life. Production Engineering Archives, 24(24), 10-13. https://doi.org/10.30657/pea.2019.24.03

Paliszkiewicz, J., Svanadze, S., \& Jikia, M. (2017). The role of knowledge management processes on organizational culture. Online Journal of Applied Knowledge Management, 5(2), 29-44. https://doi.org/10.36965/OJAKM.2017.5(2)29-44

Schein, E. H. (2016). Organizational Culture and Leadership: John Wiley \& Sons Inc.

Schein, E. H. (2018). Corporate Culture: What It Is and How to Change It: Lightning Source Inc.

Schein, E. H. (2019). Corporate Culture Survival Guide: John Wiley \& Sons Inc.

Serrat, O. A Primer on Organizational Culture, 355-358. https://doi.org/10.1007/978-981-100983-9_40

Silla, I., Navajas, J., \& Koves, G. K. (2017). Organizational culture and a safety-conscious work environment: The mediating role of employee communication satisfaction. Journal of Safety Research, 61, 121-127. https://doi.org/10.1016/j.jsr.2017.02.005

Stachová, K., Stacho, Z., Papulová, Z., \& Jemala, M. (2019). An effective selection process is the key to quality job positions occupation conditional for long-term competitiveness.

Production Engineering Archives, 24, 5-9. https://doi.org/10.30657/pea.2019.24.02

Tseng, S.-M. (2010). The effects of hierarchical culture on knowledge management processes. Management Research Review, 33(8), 827-839. https://doi.org/10.1108/01409171011065635

Zaloga, V., Dyadyura, K., Rybalka, I., Pandova, I., \& Zaborowski, T. (2020). Enhancing Efficiency by Implementation of Integrated Management System in Order to Align Organisational Culture and Daily Practice. Management Systems in Production Engineering, 28(4), 304-311. https://doi.org/10.2478/mspe-2020-0043 